\title{
Appendix A
}

\section{The Council of Europe's Strategy for Social Cohesion}

On 12 May 2000, the European Committee for Social Cohesion (CDCS) adopted its Strategy for Social Cohesion. This document, approved by the Committee of Ministers on 13 July, represents a statement of intent setting out a precise agenda for the Council in the social field for the coming years.

It does not define social cohesion as such but seeks to identify some of the factors in social cohesion, such as:

- setting up mechanisms and institutions which will prevent the factors of division (such as an excessive gap between rich and poor or the multiple forms of discrimination) from becoming so acute as to endanger social harmony;

- the importance of decent and adequately remunerated employment;

- measures to combat poverty and social exclusion, particularly in areas such as housing, health, education and training, employment and income distribution and social services;

- strengthening social security systems;

- developing policies for families, with particular emphasis on children and the elderly;

- partnership with civil society bodies, in particular trade unions, employers' representatives and NGOs.

Accordingly, social cohesion policies should:

- help to revitalise the economy and capitalise on the contribution made by the two sides of industry and other interested bodies, particularly by creating employment, stimulating enterprise and ensuring employment opportunities for all;

- meet people's basic needs and promote access to social rights within the universal spirit of the Council of Europe's many conventions and recommendations, particularly in the fields of employment, education, health, social protection and housing;

- acknowledge human dignity by focusing policies on the individual and guaranteeing human rights in Europe;

- establish forums and procedures enabling the underprivileged and those whose rights are insufficiently upheld to make themselves heard; 
- develop an integrated approach bringing together all the relevant fields of action.

The Council of Europe will be carrying out four types of activities: standard-setting activities and monitoring of the application of legal instruments; policy development; projects in member states; and research and analysis. The Strategy for Social Cohesion will naturally evolve as time goes by and as more experience is gained in this new approach by the Council of Europe.

Source: Council of Europe, 2001 